\title{
Pelatihan Kewirausahaan Dan Pengembangan Teknologi Pengolahan Kedelai Dalam Rangka Peningkatan Kualitas Produksi Olahan Minuman Sari Kedelai Sebagai Bentuk Usaha Ekonomi Kreatif
}

\author{
Nely Ana Mufarida, Aditya Dimas Pratama \\ Universitas Muhammadiyah Jember \\ e-mail: nelyana@unmuhjember.ac.id, adityadimas@unmuhjember.ac.id
}

Diterima: Februari 2021 | Dipublikasikan: Juni 2021

\begin{abstract}
ABSTRAK
Ibu-ibu rumah tangga istri karyawan UD. Arya Jaya terdiri dari 37\% usia sangat produktif (25-40 tahun) yaitu masih mampu untuk melakukan banyak hal yang dapat meningkatkan kesejahteraan keluarga. Tetapi kebanyakan hanya mengandalkan penghasilan suami untuk memenuhi kebutuhan hidup sehari-hari karena kurangnya ketrampilan dan informasi serta peluang usaha untuk meningkatkan pendapatan. Permasalahannya adalah usaha memproduksi minuman sari kedelai masih menggunakan peralatan dapur sederhana sehingga usaha rumah tangga tersebut sifatnya hanya bisnis sampingan dan tidak dikelola dengan cukup baik maka tidak dapat berkembang menjadi penghasilan utama untuk menopang perekonomian keluarga. Oleh karena itu, kegiatan pengabdian kepada masyarakat ini untuk membantu mitra masyarakat pengrajin minuman sari kedelai agar dapat memperbaiki aspek produksi secara kuantitas maupun kualitas sehingga mitra akan mendapatkan pengetahuan dan keterampilan baru mengenai pembuatan diversifikasi olahan minuman sari kedelai serta penghasilan lebih dari produk olahan minuman sari kedelai. Beberapa program untuk mengatasi masalah tersebut, antara lain: (1) Pengenalan teknologi alat mesin produksi minuman sari kedelai sekaligus melatih mitra dalam mengoperasikan alat tersebut (2) Perancangan desain kemasan dan merk/label pada kemasan produk susu kedelai untuk memudahkan konsumen dalam mengenali produk yang akan dipilih (3) Melakukan analisis STP (Segmentation, Targeting and Product) untuk meningkatkan kualitas, nilai jual, dan strategi pemasaran minuman sari kedelai.
\end{abstract}

Kata Kunci : Teknologi Pengolahan Kedelai, Minuman Sari Kedelai, Ekonomi Kreatif

\section{ABSTRACT}

Housewives of UD.Arya Jaya employees consists of 37\% very productive age (25-40 years) which is still able to do many things that can improve family welfare. But most of them only rely on their husband's income to fulfill their daily needs because of a lack of skills and information as well as business opportunities to increase income. The problem is that the business of producing soybean juice drinks still uses simple kitchen utensils so that the household business is only a side business and is not managed well enough so that it cannot develop into the main income to support the family economy. Therefore, this community service activity is to help community partners who are craftsmen of soybean juice so that they can improve aspects of production in quantity and quality so that partners will gain new knowledge and skills regarding the manufacture of diversified processed soy drinks and more income from processed soy beverage products. Several programs to overcome these problems include: (1) Introduction of machine technology for soy drink production machines as well as training partners in operating the equipment (2) Designing packaging designs and brands / labels on soy milk product packaging to facilitate consumers in recognizing products will be selected (3) Conduct STP (Segmentation, Targeting and Product) analysis to improve the quality, selling value, and marketing strategy of soybean juice drinks.

Keywords: Soybean Processing Technology, Soybean Juice Drinks, Creative Economy

\section{PENDAHULUAN}

UD. Arya Jaya merupakan usaha dagang yang bergerak dalam bidang pembuatan tahu. UD. Arya Jaya mulai beroperasi pada tahun 2003, didirikan oleh Ibu Hj. Siti Aisyah. UD. Arya Jaya berada di Kampung Bukkolan RT.01 RW.01 Desa Paowan/Kecamatan Panarukan Kabupaten 
Situbondo Provinsi Jawa Timur. Untuk menjalankan usaha ini Ibu Siti Aisyah dibantu oleh 12 orang pekerja.

Ibu-ibu rumah tangga istri karyawan UD. Arya Jaya terdiri dari $37 \%$ usia sangat produktif (25-40 tahun) yaitu masih mampu untuk melakukan banyak hal yang dapat meningkatkan kesejahteraan keluarga. Kelompok usia produktif tersebut ternyata kurang produktif, sebagian besar berprofesi sebagai ibu rumah tangga yang kebanyakan tidak memiliki penghasilan tetap dan hanya mengandalkan penghasilan suami untuk memenuhi kebutuhan hidup sehari-hari. Istri lebih sering mengurus rumah tangga dan banyak memiliki waktu luang di rumah. Di sisi lain, istri karyawan UD. Arya Jaya masuk dalam kelompok usia produktif yang berpendidikan minimal SMA/sederajat, dan belum dapat memberikan sumbangan pendapatan bagi keluarganya, karena kurangnya ketrampilan dan informasi serta peluang usaha untuk meningkatkan pendapatan.

Usaha rumah tangga yang telah dilakukan oleh anggota keluarga dan bisa dijadikan sebagai usaha sampingan dalam memenuhi kebutuhan rumah tangga yaitu usaha produksi minuman sari kedelai. Akan tetapi dalam memproduksi minuman sari kedelai masih menggunakan peralatan dapur yang ada di rumah masing-masing berupa blender, panci, serta kain saring. Usaha rumah tangga yang sifatnya hanya bisnis sampingan tersebut tidak dikelola dengan cukup baik sehingga tidak dapat berkembang menjadi penghasilan utama untuk menopang perekonomian keluarga. Oleh karena itu, usaha rumah tangga dirasa perlu untuk diperhatikan terutama oleh para stakeholder yang berperan dalam bidang kesejahteraan ekonomi masyarakat. Selain itu, dibutuhkan pula peran akademisi yang dapat membantu memecah berbagai macam persoalan yang dihadapi oleh masyarakat (mitra) dalam mengembangkan usaha.

Berdasarkan hal tersebut diatas, salah satu bentuk usaha ibu rumah tangga sebagai upaya dalam membantu perekonomian keluarga adalah dengan berwirausaha sehingga ibu-ibu rumah tangga istri karyawan UD. Arya Jaya dipilih menjadi mitra dalam kegiatan ini sehingga diharapkan memiliki tambahan ketrampilan yang dapat meningkatkan kesejahteraan keluarga.

Produk berupa minuman sari kedelai dipilih sebagai produk wirausaha, dikarenakan produk ini memiliki prospek yang baik dalam segi gizi maupun harga yang lebih murah jika dibandingkan dengan harga susu sapi. Sehingga diharapkan kegiatan wirausaha melalui penjualan minuman sari kedelai ini dapat meningkatkan penghasilan keluarga dan juga memperingan pengeluaran keluarga tanpa harus mengurangi kebutuhan gizi keluarga.

Minuman sari kedelai merupakan minuman yang berasal dari pengolahan kedelai dengan melalui proses penggilingan dan penyaringan terlebih dahulu. Bahan baku utama minuman sari kedelai yaitu berupa biji kedelai yang diperoleh baik dari hasil pertanian sendiri maupun hasil membeli dari para petani. Sari kedelai merupakan minuman dengan harga murah, memiliki nilai gizi tinggi serta cocok untuk golongan umur tua dan muda (Rohmani, dkk: 2018).

Proses pembuatan minuman sari kedelai relatif mudah untuk dilakukan oleh para pelaku usaha skala rumah tangga. Akan tetapi dalam memproduksi minuman sari kedelai masih menggunakan peralatan dapur yang ada di rumah masing-masing berupa blender, panci, serta kain saring. Proses produksi minuman sari kedelai yang biasa dilakukan melalui beberapa tahap yaitu proses penggilingan kedelai dengan blender dan proses penyaringan ekstrak kedelai dilakukan secara manual dengan menggunakan kain yang telah tersedia. Proses produksi seperti itulah yang membuat produktifitas susu kedelai mitra belum bisa optimal (Sofyan, dkk: 2018).

Kesadaran akan potensi minuman sari kedelai dan pentingnya untuk berwirausaha perlu untuk didukung dan ditingkatkan karena dapat membantu perekonomian keluarga. Selain itu, produk minuman sari kedelai sudah banyak dikenal oleh kalangan masyarakat umum sebagai minuman pengganti susu sapi karena harga susu kedelai lebih terjangkau jika dibandingkan dengan harga susu sapi.

Kegiatan pengabdian kepada masyarakat ini ditujukan kepada para kelompok ibu ibu rumah tangga istri karyawan UD. Arya Jaya untuk membantu dalam hal pendampingan mitra masyarakat pengrajin minuman sari kedelai agar dapat memperbaiki aspek produksi baik secara kuantitas maupun kualitas sehingga mitra akan mendapatkan pengetahuan dan keterampilan baru mengenai pembuatan diversifikasi olahan minuman sari kedelai serta penghasilan lebih dari 
produk olahan minuman sari kedelai. Target utama akan tercapai yaitu, Kelompok ibu-ibu rumah tangga istri karyawan UD. Arya Jaya diharapakan akan mendapatkan pemasukan dari kegiatan ekonomi kreatif demi bergeraknya roda perekonomian yang berdampak langsung bagi masyarakat, khususnya keluarga. Pada umumnya produksi minuman sari kedelai masih terkendala dengan modal dan jangkauan pemasaran yang terbatas serta peralatan yang digunakan masih sederhana sehingga diversifikasi usaha melalui pengolahan kedelai menjadi minuman sari kedelai dengan kemasan yang menarik dan berbagai varian rasa ini perlu untuk dilakukan.

Berdasarkan analisis situasi diatas, maka dapat dirumuskan beberapa permasalahan yaitu sebagai berikut:

a. Masalah utama pada program pengabdian masyarakat ini yaitu hingga saat ini dalam pembuatan minuman sari kedelai, mitra masih menggunakan kemasan yang masih konvensional. Sementara itu, penjualan minuman sari kedelai ini juga masih menggunakan cara yang konvensional, oleh karena itu perlunya adanya penerapan teknologi dan juga strategi pemasaran untuk melakukan produksi dan pemasaran minuman sari kedelai guna meningkatkan kualitas, dan nilai jual minuman sari kedelai tersebut,

b. Mitra kurang mengenal sistem pembukuan untuk manajemen dan administrasi penjualan.

c. Rendahnya keinginan masyarakat untuk mengkonsumsi minuman kesehatan. Adapun yang dimaksud dengan minuman sari kedelai pada kegiatan pengabdian ini merupakan inovasi dari minuman kesehatan yang beredar di masyarakat dengan mengembangkannya dalam kemasan siap minum dan berbagai varian rasa yang bisa bermanfaat untuk pencegahan dan pengobatan penyakit.

Program pengabdian kepada masyarakat ini mempunyai tujuan, yaitu melakukan diversifikasi usaha pembuatan minuman sari kedelai supaya mitra dapat mengembangkan usaha minuman sari kedelai yang sejauh ini belum bisa berjalan dengan maksimal. Selain itu, untuk program ini juga bertujuan untuk meningkatkan kapasitas produksi dan nilai ekonomi minuman sari kedelai serta memberikan pemahaman kepada mitra terkait sistem pemasaran minuman sari kedelai tersebut.

Guna mendukung terlaksananya tujuan tersebut, maka Tim Pelaksana memberikan pelatihan dalam pengoperasian peralatan produksi, packaging, dan pendampingan dalam proses produksi minuman sari kedelai sebagai upaya pembinaan terhadap mitra.

Berdasarkan identifikasi permasalahan yang terjadi pada mitra, akan dilakukan beberapa program untuk mengatasi masalah tersebut, antara lain:

1. Selain mutu produk, optimalisasi sistem produksi juga berpengaruh pada persaingan nilai jual produk. Proses produksi minuman sari kedelai yang efektif dan efisien harus ditunjang dengan penerapan Teknologi Tepat Guna yang dapat meningkatkan mutu produk. Penerapan Teknologi Tepat Guna dengan pembuatan mesin-mesin pengolahan dan mesin pengemasan minuman sari kedelai yang dapat meningkatkan kapasitas dan efisiensi produksi baik secara waktu, biaya maupun energi. Ilmu Pengetahuan dan Teknologi (IPTEKS) yang akan diterapkan pada program pengabdian ini yaitu pengenalan teknologi pengolahan kedelai untuk menghasilkan minuman sari kedelai dalam bentuk pelatihan kewirausahaan dengan praktik pembuatan minuman sari kedelai. Dengan adanya kemampuan memproduksi minuman sari kedelai secara mandiri, diharapkan nantinya dapat membantu kesejahteraan keluarga melalui kegiatan wirausahan penjualan minuman sari kedelai.

2. Melakukan analisis STP (Segmentation, Targeting and Product) untuk pengembangan usaha (Maharani, dkk: 2018).

\section{METODE PELAKSANAAN}

\section{Rincian Tahapan Kegiatan}

Berdasarkan solusi dan target luaran yang diusulkan dalam kegiatan pengabdian ini, maka diuraikan rincian tahapan kegiatan dalam melaksanakan solusi pada berbagai bidang, yaitu sebagai berikut: 


\section{Tahapan Metode Pelaksanaan}

Tabel 1. Tahapan Metode Pelaksanaan

\begin{tabular}{|c|c|c|}
\hline $\begin{array}{c}\text { Solusi } \\
\end{array}$ & Luaran & $\begin{array}{r}\text { Tahapan } \\
\end{array}$ \\
\hline $\begin{array}{l}\text { Program } \\
\text { Pelatihan dan } \\
\text { Pendampingan } \\
\text { pembuatan } \\
\text { minuman sari } \\
\text { kedelai }\end{array}$ & $\begin{array}{l}\text { Pengetahuan } \\
\text { dan } \\
\text { Keterampilan }\end{array}$ & $\begin{array}{l}\text { 1. Menentukan lokasi tempat pelatihan/pendampingan } \\
\text { dan persiapan alat dan bahan. } \\
\text { 2. Memotivasi warga agar mengikuti kegiatan yang } \\
\text { berkaitan dengan pengabdian pada masyarakat ini. } \\
\text { 3. Kegiatan Training yaitu pelatihan pendampingan, } \\
\text { dan penerapan pembuatan minuman sari kedelai } \\
\text { dengan tujuan agar mudah dipahami oleh mitra dan } \\
\text { supaya terjalin kerjasama dan komunikasi yang baik. } \\
\text { 4. Kegiatan Controlling System berupa pemantauan } \\
\text { dan pencatatan harian maupun mingguan untuk } \\
\text { mengetahui kemajuan dari produk minuman sari } \\
\text { kedelai. }\end{array}$ \\
\hline
\end{tabular}

\section{Tahap Pelaksanaan Kegiatan}

Kegiatan pengabdian kepada masyarakat ini menggunakan dana internal Universitas Muhammadiyah Jember. Dana tersebut digunakan untuk alokasi kegiatan pengabdian masyarakat dengan judul "Pelatihan Kewirausahaan Dan Pengembangan Teknologi Pengolahan Kedelai Dalam Rangka Peningkatan Kualitas Produksi Olahan Minuman Sari Kedelai Sebagai Bentuk Usaha Ekonomi Kreatif".

Kegiatan pengabdian kepada masyarakat ini dilaksanakan pada bulan Desember 2020. Kegiatan ini diikuti oleh 12 orang Kelompok Ibu Rumah Tangga istri Karyawan UD. Arya Jaya di Lingkungan Desa Paowan/Kecamatan Panarukan Kabupaten Situbondo dengan tahapan seperti yang ditunjukkan pada Gambar 1 berikut:

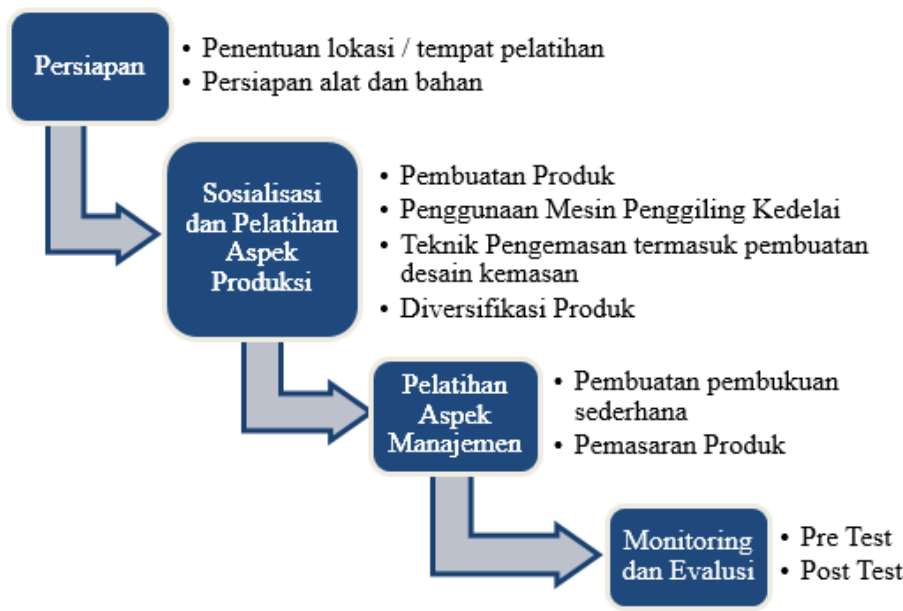

Gambar 1. Tahapan Pelaksanaan Kegiatan

Untuk program pelatihan dan pendampingan pembuatan minuman sari kedelai, Tim pengusul bertindak sebagai pelatih dan pendamping kegiatan pelatihan dan pendampingan, melakukan penilaian monev dan penggagas terjalinnya kerjasama. Sedangkan mitra bertindak sebagai peserta pelatihan dan pendampingan, pemilik dari kegiatan kewirausahaan. Pemberian motivasi dalam bentuk saling tukar pendapat/diskusi, tanya jawab, praktek, monev berkelanjutan diupayakan untuk dilakukan agar tercipta usaha kreatif mandiri. 


\section{HASIL KEGIATAN}

Kegiatan pengabdian kepada masyarakat ini menggunakan dana internal Universitas Muhammadiyah Jember. Dana tersebut digunakan untuk alokasi kegiatan pengabdian masyarakat dengan judul "Pelatihan Kewirausahaan Dan Pengembangan Teknologi Pengolahan Kedelai Dalam Rangka Peningkatan Kualitas Produksi Olahan Minuman Sari Kedelai Sebagai Bentuk Usaha Ekonomi Kreatif”.

Pada Program Kemitraan Masyarakat (PKM) ini telah dilakukan berbagai kegiatan yang diberikan kepada mitra yaitu Kelompok Ibu-Ibu Rumah Tangga di Kampung Bukkolan RT.01 RW.01 Desa Paowan/Kecamatan Panarukan Kabupaten Situbondo.

\section{A. Kegiatan Persiapan}

Tim pelaksana melakukan kegiatan koordinasi pada semua pihak yang terlibat. Para pihak yang terlibat tersebut diantaranya: ketua dan anggota pelaksana dengan mitra dan masyarakat sasaran (UD. Arya Jaya dan kolompok ibu-ibu rumah tangga) yang diwakili oleh masing-masing koordinator. Kegiatan koordinasi ini dengan tujuan untuk menyusun rencana kegiatan pengabdian yang akan dilakukan dan pembagian tugas. Koordinasi Tim Pelaksana dengan Ketua Kelompok mitra menghasilkan kesepakatan diantaranya, pelaksanaan kegiatan dilakukan di lokasi UD. Arya Jaya, peserta yang akan hadir di masing-masing kegiatan diperkirankan ada 12 orang, dan pelaksanaan akan dilakukan pada tanggal 26 dan 27 Desember 2020 sesuai dengan kesepakatan bersama. Hal yang tidak kalah penting yaitu diskusi mengenai rancangan kegiatan yang akan dilaksanakan.

Berikut ini akan dijabarkan hasil koordinasi antara ketua dan anggota pelaksana dengan mitra masyarakat sasaran secara lengkap terkait dengan susunan acara kegiatan pengabdian kepada masyarakat disajikan pada jadwal dan uraian rencana kegiatan di bawah ini.

Susunan acara kegiatan pengabdian kepada masyarakat adalah sebagai berikut:

1. Jadwal dan uraian rencana kegiatan yang dilaksanakan pada Hari Sabtu Tanggal 26 Desember 2020

\begin{tabular}{|c|c|c|}
\hline No & Waktu & Materi \\
\hline 1. & $07.30-08.30$ & Pembukaan \\
\hline 2. & $08.30-09.30$ & $\begin{array}{l}\text { Sosialisasi dan Koordinasi Tim Pelaksana } \\
\text { - Persiapan pelaksanaan pelatihan pengoperasian Mesin } \\
\text { Penggiling Kedelai } \\
\text { - Persiapan pelaksanaan pelatihan dan pembuatan minuman sari } \\
\text { kedelai }\end{array}$ \\
\hline 3. & $09.30-09.45$ & Coffee Break \\
\hline 4. & $09.45-12.45$ & Pelaksanaan pelatihan pengoperasian Mesin Penggiling Kedelai \\
\hline 5. & $12.45-13.45$ & ISHOMA \\
\hline 6. & $13.45-16.00$ & Pelaksanaan pelatihan pembuatan minuman sari kedelai \\
\hline
\end{tabular}

2. Jadwal dan uraian rencana kegiatan yang dilaksanakan pada Hari Minggu Tanggal 27 Desember 2020

\begin{tabular}{|c|l|l|}
\hline No & Waktu & Materi \\
\hline 1. & $07.30-08.30$ & Pembukaan \\
\hline 2. & $08.30-09.30$ & $\begin{array}{l}\text { Pelatihan tentang pembuatan kemasan dan stiker minuman sari } \\
\text { kedelai }\end{array}$ \\
\hline 3. & $09.30-09.45$ & Coffee Break \\
\hline 4. & $09.45-12.45$ & Pelatihan peningkatan strategi pemasaran dengan Internet Marketing \\
\hline 5. & $12.45-13.45$ & ISHOMA \\
\hline 6. & $13.45-16.00$ & $\begin{array}{l}\text { Pelatihan manajemen mengenai segmentasi Pasar dan strategi } \\
\text { pemasaran }\end{array}$ \\
\hline
\end{tabular}




\section{B. Kegiatan Sosialisasi kepada Mitra}

Pada kegiatan ini Tim Pelaksana melakukan kegiatan sosialisasi dan koordinasi tentang persiapan pelaksanaan pelatihan pengoperasian mesin penggiling kedelai dan persiapan pelaksanaan pelatihan pembuatan minuman sari kedelai kepada Mitra PKM yaitu UD. Arya Jaya dan Kelompok Ibu-Ibu Rumah Tangga. Pada kegiatan ini, Tim Pelaksana melakukan koordinasi dalam hal persiapan berbagai kegiatan yanga dilakasanakan pada hari Sabtu 26 Desember 2020 pukul 08.30 - 09.30. Kegiatan ini bertempat di Kampung Bukkolan RT.01 RW.01 Desa Paowan, Kecamatan Panarukan, Kabupaten Situbondo dan dihadiri oleh perwakilan dari Mitra.

\section{Kegiatan Pelatihan dan Pendampingan}

1. Kegiatan Pelatihan Pengoperasian Mesin Penggiling Kedelai

Kegiatan Pelatihan dan Pendampingan ini dilaksanakan pada hari Sabtu 26 Desember 2020 pukul 09.45 - 12.45 dan bertempat di UD. Arya Jaya Situbondo. Yang hadir sebanyak 12 peserta. Kegiatan berlangsung dengan lancar dan berjalan sesuai rencana sebelumnya. Dari mulai menyiapkan bahan dan mesin penggiling kedelai. Para peserta sangat antusias.

\section{Kegiatan Pelatihan pembuatan minuman sari kedelai}

Kegiatan Pelatihan dan Pendampingan ini dilaksanakan pada hari Sabtu 26 Desember 2020 pukul 13.45 - 16.00 dan bertempat di Ruang Dapur UD. Arya Jaya Situbondo.Yang hadir sebanyak 12 peserta. Kegiatan belangsung dengan lancar dan berjalan dengan sesuai rencana sebelumnya. Dari mulai menyiapkan bahan dan peralatan masak.

\section{Kegiatan Pelatihan Peningkatan Strategi Pemasaran}

Pada kegiatan pelatihan peningkatan strategi pemasaran dilakukan pada hari Minggu tanggal 27 Desember 2020. Tempat pelatihan peningkatan strategi pemasaran berlokasi di Aula UD. Arya Jaya Situbondo. Banyaknya peserta yang hadir pada acara tersebut sejumlah 12 orang yaitu Kelompok Ibu-Ibu rumah Tangga Kampung Bukkolan Desa Paowan Kecamatan Panarukan Kabupaten Situbondo.

Pada kegiatan tersebut diberikan pelatihan strategi pemasaran yang efektif dengan memanfaatkan layanan e-commerce maupun media sosial. Selain itu juga, diberikan beberapa pengetahuan cara mengelola keuangan dengan baik dan benar yaitu dengan menggunakan pembukuan sederhana dan juga menggunakan aplikasi yang sudah tersedia pada perangkat komputer. Sebagai contoh, menggunakan aplikasi yang selalu dipakai yaitu Microsoft Excel. Kegiatan ini begitu penting untuk dilaksanakan demi keberlanjutan usaha minuman sari kedelai. Karena pada dasarnya, usaha akan berjalan dengan baik jika pemasaran dan pengelolan keuangan yang baik pula. Pada pelaksanaan kegiatan tersebut berjalan dengan lancar dan sesuai dengan rencana yang telah dibuat sebelumnya.

Melalui diskusi dan koordinasi antara Mitra Usaha dan Tim Pelaksana Program Kemitraan Masyarakat (PKM) maka diambil beberapa keputusan untuk meningkatkan strategi pemasaran melalui internet marketing diantaranya:

1. Penggunaan media sosial seperti facebook dan instagram agar dapat melakukan promosi dan penjualan dengan mudah dan murah, mengingat kedua media sosial tersebut memberikan fitur halaman bisnis dan telah banyak digunakan oleh beragam kalangan masyarakat. Selain itu, media sosial Whatsapp juga bisa digunakan sebagai sarana promosi dan penjualan dengan cara mengunggah foto produk ke status.

2. Pengelolaan seluruh aplikasi internet marketing agar dapat terus berkembang dan berkelanjutan untuk menarik minat konsumen untuk membeli.

Untuk menindaklanjuti diskusi tersebut maka selanjutnya dilakukan kegiatan sebagai berikut:

1. Melakukan pembuatan media sosial facebook yaitu Misake Sari Kedelai, instagram @Misakesarikedelai dan Whatsapp sebagai media promosi dan penjualan produk. Konsumen diharapkan dapat mengetahui produk sekaligus dapat memesannya langsung melalui media sosial tersebut. Penggunaan facebook dan instagram dikarenakan pada kedua media sosial tersebut memiliki fitur halaman bisnis yang mampu memberi peluang produk untuk dikenal lebih banyak orang. Penjualan dan promosi melalui Whatsapp dengan cara mengunggah foto produk ke status. 
2. Melakukan pelatihan membuat konten yang menarik, promosi di media sosial, mencari target konsumen, dan bentuk pelayanan customer service online pada Instagram, facebook dan Whatsapp.

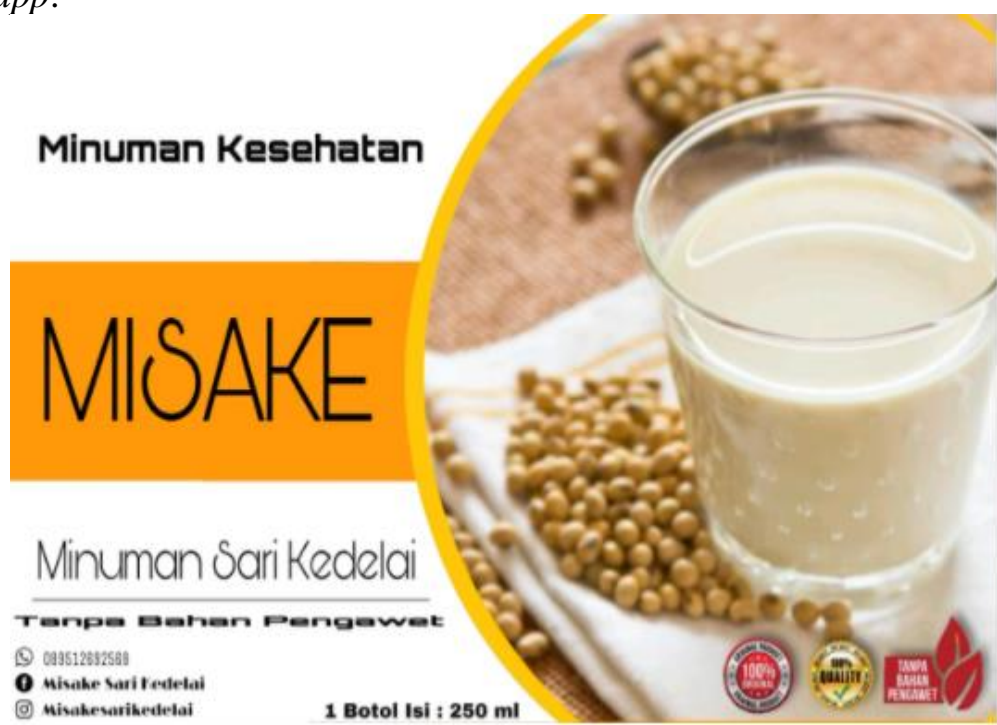

Gambar 2. Contoh Tampilan Promosi Penjualan

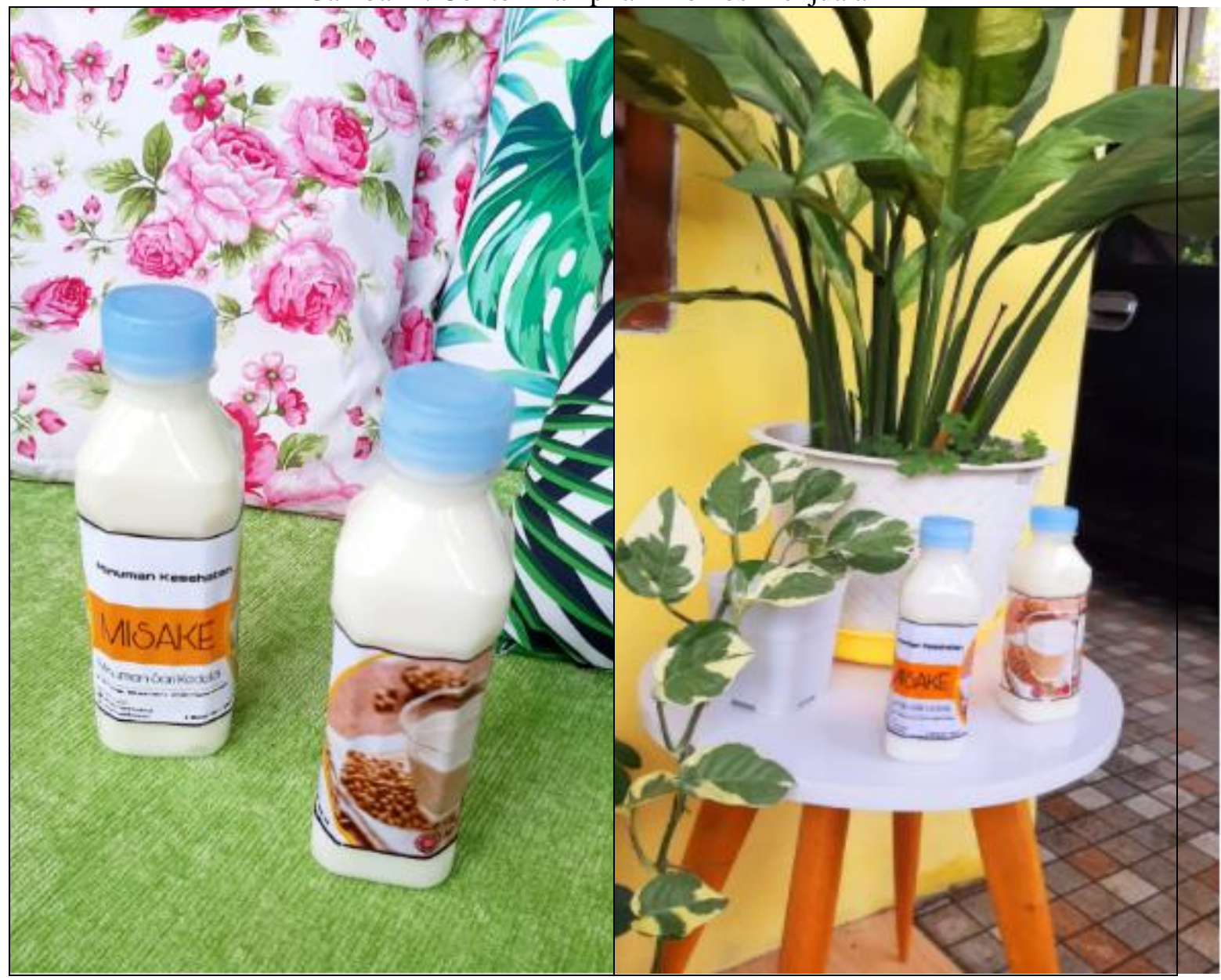

Gambar 3. Minuman Sari Kedelai "MISAKE"

KESIMPULAN DAN SARAN 


\section{Kesimpulan}

Berdasarkan hasil kegiatan Program Kemitraan Masyarakat (PKM) Stimulus berupa Pelatihan Kewirausahaan Dan Pengembangan Teknologi Pengolahan Kedelai Dalam Rangka Peningkatan Kualitas Produksi Olahan Minuman Sari Kedelai Sebagai Bentuk Usaha Ekonomi Kreatif di Kampung Bukkolan RT.01 RW.01 Desa Paowan, Kecamatan Panarukan, Kabupaten Situbondo Provinsi Jawa Timur diikuti 12 peserta Kelompok Ibu-Ibu rumah Tangga, diperoleh kesimpulan sebagai berikut:

1. Tim Pelaksana telah melakukan berbagai kegiatan yang dilaksanakan pada Hari Sabtu Tanggal 26 Desember 2020 antara lain:

a) Sosialisasi dan Koordinasi Tim Pelaksana

- Persiapan pelaksanaan pelatihan pengoperasian Mesin Penggiling Kedelai

- Persiapan pelaksanaan pelatihan dan pembuatan minuman sari kedelai

b) Pelaksanaan pelatihan pengoperasian Mesin Penggiling Kedelai

c) Pelaksanaan pelatihan pembuatan minuman sari kedelai

2. Tim Pelaksana telah melakukan berbagai kegiatan yang dilaksanakan pada Hari Minggu Tanggal 27 Desember 2020 antara lain:

a) Pelatihan tentang pembuatan kemasan dan stiker minuman sari kedelai

b) Pelatihan peningkatan strategi pemasaran dengan Internet Marketing

c) Pelatihan manajemen mengenai segmentasi pasar dan strategi pemasaran

Saran

Berdasarkan hasil pengamatan dan interaksi langsung dengan Mitra maka didapatkan kesan kooperatif dan menerima masukan dari Tim Pelaksana Program Kemitraan Masyarakat (PKM) Pelatihan Kewirausahaan Dan Pengembangan Teknologi Pengolahan Kedelai Dalam Rangka Peningkatan Kualitas Produksi Olahan Minuman Sari Kedelai Sebagai Bentuk Usaha Ekonomi Kreatif.

Berdasarkan pembahasan yang diuraikan pada bab-bab sebelumnya maka dikemukakan saran sebagai berikut:

1. Sebelum proses pengolahan dengan menggunakan mesin penggiling kedelai, sebaiknya kedelai direndam selama 4-12 jam dengan takaran 10-12 liter air untuk $1 \mathrm{~kg}$ kedelai ,dengan catatan tidak perlu sampai menjadi cambah.

2. Dari segi pemasaran yang belum terbiasa online, maka perlu adanya pelatihan manajemen mengenai segmentasi pasar dan strategi pemasaran dan upaya pendampingan secara berkala untuk terus dilakukan untuk menjaga kualitas produk dan penambahan wawasan bagi sumber daya manusia yang dimiliki mitra usaha agar pemasaran produk yang dihasilkan semakin optimal.

3. Selain itu perlu tindak lanjut dari pembuatan media sosial dan layanan e-commerce sebagai salah satu sarana pemasaran yang efektif dan efisien.

\section{DAFTAR PUSTAKA}

Maharani, A dan Sholihah, D. 2018. Peningkatan Kualitas Produk Kerupuk Sebagai Komoditas Pangan Islami Pada Industro Kerupuk Di Kabupaten Jember. Laporan Akhir Program Kemitraan Masyarakat. Jember: Universitas Muhammadiyah Jember.

Rohmani, S., Yugatama, A., dan Prihapsara, F. 2018. Inovasi Minuman Sehat Berbahan Kedelai dalam Upaya Pemberdayaan Masyarakat melalui Wirausaha di Kabupaten Sukoharjo. Agrokreatif Jurnal Ilmiah Pengabdian kepada Masyarakat, 4(1):68-74.

Sofyan, A., Markhamah, Ikhsani, A.Y., Lestari, Septiana, N.A.D., Rahmawati, D.T., Nisa, Z.R., dan Rohman, G.J.N. 2018. Peningkatan Kapasitas Produksi dan Perbaikan Kualitas Produk Susu Kedelai Skala Rumah Tangga Melalui Program Kemitraan Masyarakat. Prosiding Seminar Pengabdian Kepada Masyarakat (Senadimas) 2018. 